\title{
Odour as trace evidence
}

\author{
Ewa Jurczyk-Romanowska \\ e.jurczyk@prawo.uni.wroc.pl
}

\begin{abstract}
:
There are a number of scent classification systems that typically take into account the similarities and differences in human olfactory perception, regardless of what chemical compounds cause a particular sensation. Also there is no objective, physical or chemical basis for the classification of odours, unlike eyesight or hearing. In fact, until now, scientists cannot explain, how it happens, that we can detect different scents. The present paper compares theories and classifications of human scent.
\end{abstract}

Key words: individual human scent, human scent identification, classification of human scent, scent theories, human odour, osmology, odourology.

When considering the importance of human odour trace in criminal investigation an attempt must first be made to answer the question: what is an odour? This concept, commonly known and used, is not, however, unequivocally defined and classified as a scientific notion. Scent is defined as a sensation caused by the stimulation of olfactory receptors by certain volatile chemical substances (Jezierski 1999, p. 6); the notion relates to gas substances entering the nasal cavity along with air, with the source of the scent placed at a distance from a person or an animal.

A primary (basic) odour is a scent that is registered by what is probably a separate type of olfactory receptor. The data concerning the presumed existence of separate olfactory receptors is contradictory. Some sources claim that there are no morphological differences in the structure of olfactory cells; it is, therefore, unknown, whether the primary odours are in fact related to separate sensors (Jezierski 1999, p. 18).

A smell, as sensed by humans and animals, is transmitted by molecules known as odour molecules. In the natural environment the molecules are usually combined into socalled bouquets. Because of this, the odour of each particular substance is made up of a fixed number of olfactory components, combined in appropriate proportions, e.g. the coffee aroma, containing 400 components, or the human odour, with its 401 components (Kulicki 1994, p. 
281). It is to be taken into consideration that even minor changes in volume or proportion may considerably alter the odour.

There are a number of scent classification systems that typically take into account the similarities and differences in human olfactory perception, regardless of which chemical compounds cause a particular sensation. These are, therefore, subjective classification systems, with an objective odour scale being possibly useful only in case of a description of an odour being provided, without a scent trace being secured at a crime scene (Karocki, Widacki 1972, p. 63-71). Developing a proper objective classification system of odours is made difficult by their great number. Some specialists claim that it is impossible to differentiate primary odours, as in the case of primary colours or sounds, and that it may be assumed that there are just as many odours as there are objects that give them off. That is why the names of odours are typically derived from the names of the substances that have the immanent characteristic of a certain odour. Yet another difficulty in the classification of odours is the unlimited number of odour mixtures.

Therefore, a complete and universal odour classification system does not exist. The most widely known of the subjective classifications are:

1. The C. Linnaeus classification:

a) aromatic odour, e.g. that of a clove,

b) fragrant odour, e.g. that of a lily,

c) musky odour, e.g. that of musk,

d) alliaceous odour, e.g. that of garlic,

e) hircine odour, e.g. that of valerian,

f) repulsive odour, e.g. that of a bedbug,

g) nauseous, e.g. that of carrion.

2. The H. Zwaardenemaker classification, being an attempt at qualitative classification and distinguishing 9 groups:

a) ethereal odours, e.g. those of ether, apples, wine, beeswax,

b) aromatic odours, e.g. those of camphor, spices, aniseed, lemons, almonds, turpentine,

c) fragrant odours, e.g. those of flowers, tea, vanilla,

d) musky odours, e.g. those of amber, musk,

e) alliaceous odours, e.g. those of onions, garlic, caoutchouc, acetylene, chlorine, iodine, 
f) empyreumatic odours, e.g. those of roasted coffee, baked bread, tobacco smoke, kerosene, asphalt, carbolic acid,

g) hiccine odours, e.g. those of old cheese, sheepskin, perspiration,

h) foul odours e.g. those of opium, bedbugs,

i) nauseous odours, e.g. that of carrion (Jezierski 1999, p. 6).

The criteria of the aforementioned classification systems are unclear and the distribution of odours incomplete.

3. The H. Henning classification, the so-called "smell prism", containing 6 groups:

a) flowery,

b) foul,

c) fruity,

d) spicy,

e) burnt,

f) resinous (Karocki, Widacki 1972, p. 63-71).

In this division many of the shortcomings of former classifications have been eliminated. Because, presented as a prism, it is possible to position intermediate odours. Despite the difficulties in localizing some odours within the prism, this classification is considered one of the best.

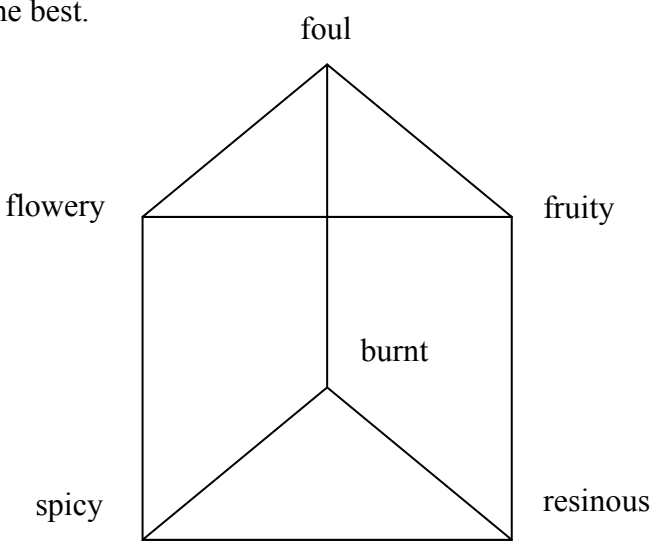

Fig. 1. Henning's "smell prism", source: Jezierski 1999, p. 19

4. The J. E. Amoore's classification. The originator of the stereochemical theory of odour (discussed below) proposed that the odours of chemical substances are dependent on the shape of their molecules which, in turn, fit into complementary olfactory receptor sites. Based on these assumptions, the odours of organic substances have been divided into three 
groups: primary odours, complex odours and the odours belonging to both former groups (Wright 1972, p. 169-173).

\begin{tabular}{|c|c|}
\hline PRIMARY ODOURS & COMPLEX ODOURS \\
\hline camphor & lemon \\
\hline acrid & cedar \\
\hline ethereal & alliaceous \\
\hline flowery & rancid \\
\hline mint \\
\hline musky \\
\hline foul \\
\hline \multicolumn{2}{|c|}{ almond, aromatic, aniseed } \\
\hline
\end{tabular}

Fig. 2. Classification of odours according to J. E. Amoore, source: Wright 1972, p. 169

5. The Crocker-Henderson classification - each complex odour is represented by a four-digit number. 4 primary odour qualities have been posited:

a) fragrant - A,

b) acid - B,

c) burnt $-\mathrm{C}$,

d) caprylic $-\mathrm{D}$.

The qualities are given in a fixed order and their intensity is described with digits 0 to 8. For example, the rose odour has the number 6423 (ABCD), it is, then, a primarily fragrant odour, with less intensive acid quality, etc. This classification is used in some countries by the perfume industry. However, with its use certain difficulties arise as to the choosing of one of the qualities and determining the intensity of each of the 4 qualities (Jezierski 1999, p. 20).

6. Classification according to the place where certain odours are typically found - e.g. appetizing, hospital, church, home, laundry, and workshop odours (Jezierski 1999, p. 20).

There is no objective, physical or chemical basis for the classification of odours, unlike eyesight or hearing. There is no clear-cut relationship between odours and the molecular structure of odorants. Chemically similar substances tend to give off similar odours; the same scent may, however, be given off by chemically unrelated substances (Karocki, Widacki 1972, p. 63-71). Odours are sensed when odorant molecules adhere to the cellular membrane - that process is known as adsorption. The cell membrane is primarily lipid and enclosed in mucus. An odorant molecule must be transported though the air to the lipids-water layer (Wright 1972, p. 118). Volatile molecules come in touch with the olfactory epithelium along with the air from the outside while inhaling, or with the air from the oral 
cavity while exhaling. The molecules adhere to the mucous membrane stimulating the cilia of the olfactory cell. A few theories explaining the transformation of olfactory impulses into nerve impulses and the transmitting of olfactory information through nerve cells exist.

The vibration theory of olfaction assumes the transmitting of information through vibrations of atoms or electrons. According to the infrared loss theory of olfaction, the heat radiation of the nerve cells is absorbed by the odorant molecules. The chemical theory assumes that a volatile chemical substance enters the nerve cells of the olfactory epithelium and combines with their protein substances. The composition of different substances varies, therefore numerous protein-based compounds are created, which, in turn, lead to the differentiation of nerve impulses reaching the brain. It is assumed that there are no particular nerve fibers for individual odours. A fiber may react to different odours; however, the frequency of discharge and the length of the latent phase may vary. According to the theory, a particle, having dissolved in the mucus surrounding the olfactory epithelium, stimulates the receptors, causing them to depolarize (Jezierski 1999, p. 20).

The stereochemical theory of olfaction, formulated in 1952 by J. Amoore, is generally based on the so-called "lock and key" mechanism at various levels of reception by the membrane, especially in the area of the synapses. According to the theory, molecules of similar stereochemical shape have similar odour. The level of detectability of an olfactory impulse is determined by how far a molecule of the impulse is compatible with the membrane receptor of an olfactory cell. The stereochemical theory assumes the existence of a few primary olfactory impulses (keys), for which there are to be a number of clearly defined receptors (locks), to be found on the olfactory cell membrane. Those olfactory impulses are to be a basis for a great number of complex odours (Jezierski 1999, p. 11).

The oscillatory theory, formulated in 1999 by L. Turin, proposes that substances that are chemically alike do not necessarily produce similar odours; this assumption being a challenge to the stereochemical theory of J. Amoore. The phenomenon of odour sensing is explained by L. Turin as follows. When a molecule enters a receptor, electrons are flowing through it. The electron flow causes a chemical reaction stimulating the neuron to transmit a signal to the brain with the information about a certain molecule having entered the receptor. The electron flow identifies the molecule by a particular oscillation of the inter-atomic bonds. Thus, what determines an odour is not the shape of a molecule, but the characteristic oscillation of the bonds that is to a molecule like a fingerprint is to a human being (Turin 2006, p. 130-141). 
It must be taken into account that the theories explaining the process of odour sensing presented above are only an attempt at a scientific explanation of the key notions connected with odour. However, no common agreement has been reached as to the essence of that atypical trace in criminal investigation, which is a problem, in my opinion, because without knowing the process of odour sensing we assume that it may be subject to osmological analysis, which in a criminal action takes the form of an expertise. We, therefore, decide to issue categorical opinions as to the origin of two odours from one person. The authors concerned with this subject matter attempt to address this problematic ambiguity by introducing a whole range of theories (Karocki, Widacki 1972, Wright 1972, Jezierski 1999) or ignoring the matter altogether (Bednarek 2007, p. 187-208).

The quality and intensity of human odour depends on numerous external factors, such as environment temperature, humidity, etc., as well as internal factors, such as emotional state, health, diet, age, etc. The odour of a calm person is distinctly different from that of a frightened one, just as the odour an sick person differs from that of a healthy person, or an old person from a young one. Odour is an individual element of every man; it is typical of only one particular person, just as fingerprints or genetic code. To exemplify the distinct individuality of odour it may be compared to the human face. One's face may take on various expressions, the skin colour may change, depending on external factors such as heat, cold, makeup, wind, or internal factors, such fear, anger, joy, pain, etc.; the face changes with age, however, it is still the same face, distinct from all other faces that are or will be (Godlewski, Rogowski, Gawkowski 1998, p. 23-37). If a dog could speak, he would tell us: there are just as many odours as there are men, dogs, cats, rabbits, deer, and all the creatures in the world that posses an odour, and many more. Yet one cannot find two beings that smell the same. Even the odours of identical twins differ. Dogs with particularly acute noses can tell them apart (Godlewski, Rogowski, Gawkowski 1998, p. 23-37).

Human odour is genetically conditioned and does not depend on factors such as diet, clothing, domestic environment. Thus, substances determining one's odour that are found in blood, sweat and sebaceous glands, peeled-off epidermis, hair, secretion of the pharyngonasal cavity, external genitalia, are genetically conditioned. The distinctiveness of odour is determined by the qualitative and quantitative differences in the composition of the substances conditioning human scent (Bednarek 1998, p. 32-34).

There are numerous sources of dermal secretion, e.g. sebaceous glands and sweat glands. Aliphatic (fatty) acids are found in sweat, sebum and peeling epidermis. According to R.H. Wright, on the sole of the human foot there are only sweat glands, albeit in great number 
(over 1000 per $1 \mathrm{~cm}^{2}$ ). In 24 hours a human body secretes about $800 \mathrm{~cm}^{3}$ of perspiration, with about $2 \%$ of the daily amount produced by each foot, which makes about $16 \mathrm{~cm}^{3}$. Human sweat contains $0,156 \%$ acid, about a quarter of which is aliphatic acids. If only $1 / 1000$ part of that amount penetrates through the sole of a shoe and stitches it may be calculated that, for example, in each footprint there will be $2.5 \times 10^{11}$ molecules of butyric acid left. That is over a million times above a dog's scent threshold concentration and may be detectable even diluted in $28 \mathrm{~m}^{3}$ of air (Wright 1972, p. 67). In normal conditions, the evaporation rate of a substance depends on the environment temperature and ground absorption properties. Thus, it may be stated that in optimal weather conditions such a trace might still be used after over 24 hours. W. Neuhaus claims that the calculated amount of fatty acids left in a footprint is above the human scent threshold concentration, as well, so even a man could follow a fresh trace using the sense of smell (Wright 1972, p. 67). Having analyzed the behaviour of dogs, another researcher in that field $-\mathrm{K}$. Most - came to the conclusion that a scent trace is a complex impulse. The impulse is composed of:

a) the scent of soil triggered by increased evaporation rate (caused by pressure),

b) the scent of crushed vegetation,

c) the scent of shoes and shoe polish,

d) the scent of decomposing organic animal matter,

e) the scent of person-specific body odour (Lenkiewicz 1959, pp. 613-634).

An example of a scent trace devoid of any impulses except human body odour would be that of a bare footprint on glass, but, in reality, such traces are rarely found (Lenkiewicz 1959, p. 613-634).

Having conducted research of his own, W. Neuhaus came to the conclusion that a dog does not recognize a particular person's odour based on some single, person-specific chemical substance, but through an odour pattern or complex, which may in its character be influenced even by the substances appearing in amounts below the scent threshold concentration (Jezierski 1999, p. 17).

It turns out that dogs recognize samples of human scent regardless of the part of the body they were taken from, even if the scent is mixed with other odours. Odour type is genetically conditioned, because only identical (uniovular) twins have the same genetic structure, with their odours being apparently similar, although not identical. It might be compared to a situation when we meet one of the twins out on the street and we have no idea which one it is, however, we have no problem telling them apart when the twins are standing next to each other. 
An interesting structure of human scent has been proposed by A. Winberg, with the scent considered a complex of multiple odours; this assumption is the basis for distinguishing of topical odours, individual odour and general odour.

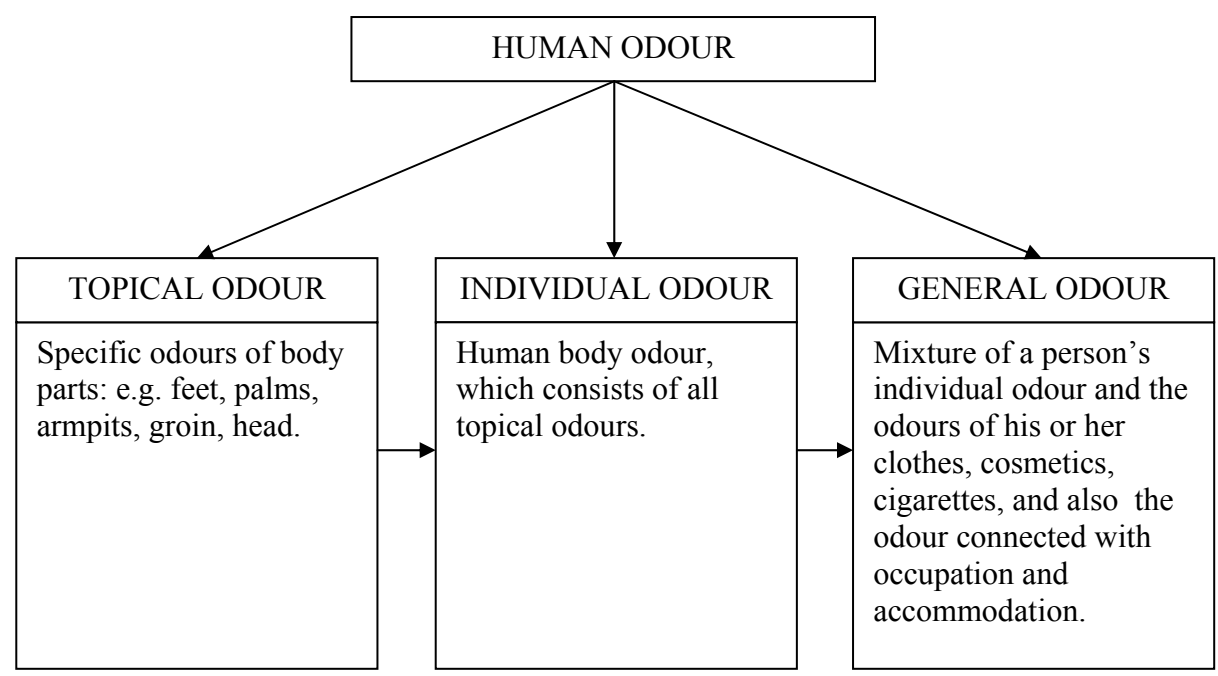

Fig. 3. The structure of human odour by A. Winberg, source: Lachacz 1998, p. 8

Referring to the aforementioned types of human odour it may be proposed that it is, in fact, a complex of odours, wherein internal and external odours are to be distinguished, as illustrated below: 


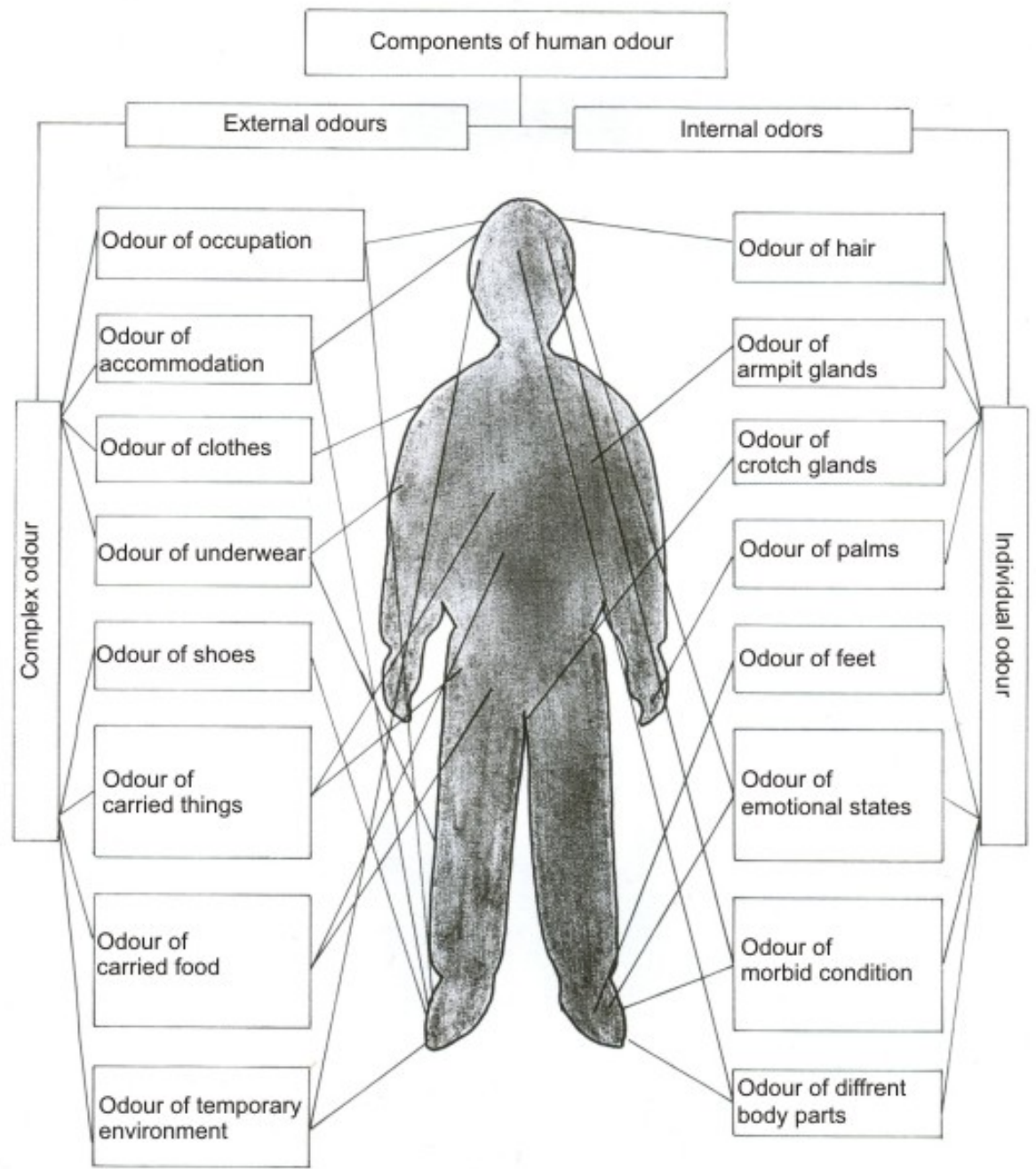

Fig. 4. The structure of human scent, source: Lachacz 1998, p. 11

Thus, each living creature has its own distinctive individual scent. This position is supported by biologists, medical doctors, cynologists, and most criminologists. The leaving of this delicate trace cannot be avoided; one always leaves a scent, wherever one goes. It is one's "signature", as it were, that should be made use of properly.

When discussing scent traces it must be taken into account that it is a functional term referring to a living organism and to those molecules and compounds that are capable of causing olfactory perceptions (Bednarek 1999a, p. 16). Odour traces, taking into account one 
of the basic divisions of trace evidence, with its criterion being matter structure in which the trace is left, must be categorized as substantive (physical) traces (Bednarek 1998, p. 32-34), since they are made up of molecules evaporated from the inside or the surface of a substance. The scent trace is a natural remnant of all living organisms and it is left at a crime scene whenever the perpetrator comes in contact with any object whatsoever.

According to osmology specialists, the odour trace is to be defined as olfactory molecules that have been disclosed, fixed and secured at the crime scene or in a laboratory, left by an individual carrier on objects and persons related to the crime scene (Godlewski 1998, p. 57-63).

Odour trace evidence occupies a central position in the field of scent identification, although the notion itself is not clearly defined and a source of controversy among the specialists in forensic science and cynology (Godlewski, Rogowski, Gawkowski 1998, p. 2337). In osmology it is assumed that trace evidence is a composition of molecules of fatty acids produced by the entire body mixed with additional odours (odour background) related to one's occupation, environment, cosmetics, etc. (Godlewski, Rogowski, Gawkowski 1998, p. 23-37). Another definition that needs to be mentioned is that of an olfactory molecule - the term referring to the primary unit allowing for the identification of the carrier of an odour trace, that is, the individual scent combined with the odour background. As the physical characteristics of an odour trace remain unknown, a clear defining of the notion of odour trace evidence is a cause of the aforementioned difficulties (Godlewski, Rogowski, Gawkowski 1998, p. 23-37). It is certain, however, that odour trace is a natural remnant of all living organisms.

Changes of environment, changes of climate and chemical factors are known to have a negative influence on the durability of scent traces, causing their weakening and deformation and leading to difficulties with and the prolonging of the process of odour trace fixing, which, in turn, has a negative impact on the possibility of using secured odour trace evidence in osmological studies. An important factor in the fixing of odour traces is the delay time, i.e. the time between the moment of imprinting and the moment of fixing of the odour trace (Godlewski 1998, p. 57-63). Furthermore, odour trace evidence is secured as autonomous trace evidence.

A series of tests on odour trace evidence was performed in the Centre for Criminal Expertise in Russia in the ' $90 \mathrm{~s}$, which led to the conclusion that it is, in fact, governed by the same rules as other types of trace evidence; it is, therefore, characterized by: 
1. Uniqueness - taking into account that the organisms that are genetically the most similar are identical twins a series of tests was performed where material sublimed from the blood of a pair of twins was placed in a selection sequence. The dogs smelled the odour of only one of the twins and only that one they actually identified. No reaction to the other twin was observed (Bednarek 1999b, p. 40-45). The uniqueness of human odour is proven indirectly: if the odour is undoubtedly influenced by genes responsible also for the immunological system, then judging by how hard it is to find an organ donor with compatible tissue material a conclusion may be drawn as to the individuality of human odour and the probability of finding an identical scent being comparable with the probability of finding a person with an identical DNA profile (Wójcikiewicz 2000, p. 37-43).

2. Constancy - a series of tests was performed, where odour traces collected from blood were compared with material collected from the same persons 15 years earlier. The dogs from the Centre for Criminal Expertise unequivocally affiliated the materials (Bednarek 1999b, p. 40-45). The constancy of human odour is relative, because there is a possibility of distinguishing between the odours of children and adults. It may be assumed that an odour is unchangeable at least in some important part, since it is based on the human genome (Wójcikiewicz 2000, p. 37-43).

3. Irremovability - strictly connected to constancy. Tests on dogs have demonstrated that individual human odour remains on human hair for up to 23 years. It has also been experimentally proven that individual human odour remains in desiccated traces of blood for up to 15 years (Bednarek 1999b, p. 40-45). An odour trace in such cases needs to be correctly collected, fixed, secured and stored.

The best "odour carriers" and sample sources are biological traces: blood, sweat and tissue fragments. They preserve their unique qualities for the longest periods of time - up to a few years (Widacki 1998, p. 102-108). Personal belongings that have been in contact with the human body for prolonged periods of time, such as underwear, or pieces of clothing, especially those that are in close contact with the body, namely socks, shoes, gloves, hats may preserve a scent perceptible to a dog for up to 20 months. Human odour traces remain on any objects that one has been in contact with. If the contact lasted for longer than 30 minutes the odour trace, in favorable conditions, may be preserved for up to 24 hours. On objects that have been in contact with a body for short periods of time (less than 30 minutes) human odour traces may be preserved for up to 20 hours (Widacki 1998, p. 102-108). The footprints of shod feet preserve the scent for up to 10 hours, or, in some cases, longer. An odour trace remains for prolonged periods on absorbent surfaces and it is preserved much shorter on 
smooth, impermeable surfaces; it is preserved for long periods in confined, isolated spaces, etc. (Widacki 1998, p. 102-108).

The odour trace of a perpetrator may be left upon objects, on the ground or above it in the form of invisible particles, i.e. odour molecules. Every human being produces individual odour, governed by physiological and pathological processes, that is very quickly absorbed by underwear, clothes and shoes (even those made of rubber). Combined with the scents of one's work place, home and cosmetics, an individual odour is created (Kuczys, Milewski 1973, p. 341-343), which, during the process of the adsorbing of odour molecules upon surfaces of the objects one has been in contact with, may constitute trace evidence to a criminologist, or a source of information to a dog (Biestek, Malec 1999, p. 42-44).

Trace evidence is a primary type of physical evidence that forensic science (criminalistics) deals with, although there is no commonly accepted definition of the notion of trace. Some specialists assume that it is a perceivable change in objective reality, being a result of the event that is subject to criminal investigation, while other authors propose that it may be any remainder whatsoever of an event that a forensic scientist is able to recognize and make use of (Czeczot, Tomaszewski 1996, p. 171-174). Yet another definition of "trace" states that it is any remainder of an event that may serve as evidence of the event taking place; furthermore, trace is not only a material remainder of an event, but may as well be a factor materially imperceptible that might have been the cause of the event, e.g. a thunderbolt. Hans Gross, the author of the first forensic science textbook in history, defined traces as all imprints and impressions in a yielding material that are undoubtedly connected to the act.

We must bear in mind that all events, including crime, leave traces in their wake. A "perfect crime" is a myth made popular by crime fiction. No one, not even the most intelligent of perpetrators, is able to avoid leaving traces at the crime scene and any attempts made to remove the traces may, in fact, provide additional information connected to the crime. It must be emphasized that one trace that a perpetrator can never avoid leaving is scent.

With the development of forensic science the notion of trace and its structure change, with the structure understood as the number and types of characteristics prone to investigation. This thesis is clearly illustrated by the example of a footprint (bare or shod). Only recently this notion was defined as a perceptible print in a yielding base (footprints on clay, sand, snow, etc.) or a surface footprint trace (exfoliated on a dusty surface or overlaid on a clean one). Contemporarily, a footprint may also be understood as:

1. imperceptible micro-recess left by a foot on linoleum, rubber or similar floor covering, revealed by holographic methods, 
2. imperceptible static charge on a plastic base (a covering or a carpet) spread out on the surface in a way that allows for the projection of the shape of a foot,

3. imperceptible thermal trace left on any sort of base, involving heat radiating from a surface (Kołecki 1975, p. 453-461),

4. an odour trace imperceptible to men.

Human odour is gaining importance as trace evidence; it must be taken into account that it is also the most fragile of all traces and requires proper handling. However, the securing, storing and duplicating of odour trace evidence is beyond the subject matter of this article.

Recapitulating, it must be stated that odour trace evidence has made a lasting impact on Polish forensic science. A series of tests has been performed that justify the conclusion that odour trace evidence is characterized by three features that ascertain its belonging to physical evidence - uniqueness, constancy and irremovability. Polish forensic science often identifies persons based on their individual odours, which is a part of forensic expertise and has repeatedly been introduced as evidence in a court of law.

However, we must not forget that it is basically the only trace whose structure and working mechanisms have not as of yet been scientifically explained, with a number of aforementioned hypotheses as to the essence of its functioning formulated. Theories not supported by irrefutable scientific research should not constitute a basis for categorical judgment, with positive categorical expertise being a judgment of that sort, since it might bear grave consequences for a suspect in a crime.

\section{Bibliography:}

Bednarek T. (2007), Ślady osmologiczne, [in:] Goc M., Moszczyński J. (eds.), Ślady kryminalistyczne. Ujawnianie, zabezpieczanie, wykorzystanie, Difin, Warszawa.

Bednarek, T. (1998), Podstawowe zagadnienia z badań osmologicznych, "Problemy Kryminalistyki" 222.

Bednarek, T. (1999a), Chemia w sukurs osmologii, "Problemy Kryminalistyki” 223.

Bednarek T. (1999b), Badanie śladów zapachowych - przeceniany czy niedoceniany dziat kryminalistyki, "Palestra" 7-8.

Biestek K., Malec K. (1999), Próby określania możliwości przeniesienia zapachu z osoby na osobe za pośrednictwem przedmiotu oraz z przedmiotu na przedmiot za pośrednictwem osoby, "Problemy Kryminalistyki” 226.

Czeczot Z., Tomaszewski T. (1996), Kryminalistyka ogólna, COMER, Toruń. 
Goc M., Moszczyński J. (2007) (eds.), Ślady kryminalistyczne. Ujawnianie, zabezpieczanie, wykorzystanie, Difin, Warszawa.

Godlewski J. (1998), Osmologia w pigutce, "Policyjny Biuletyn Szkoleniowy”, 1-2.

Godlewski J., Rogowski M., Gawkowski M. (1998), Praktyczne podstawy osmologii kryminalistycznej, [in:] Gruza E., Tomaszewski T. (eds.), Problemy współczesnej kryminalistyki, Wydawnictwo Zakładu Kryminalistyki UW, Warszawa.

Gruza E., Tomaszewski T. (1998) (eds.), Problemy współczesnej kryminalistyki, Zakład Kryminalistyki UW, Warszawa.

Jezierski T.A. (1999), Podstawy fizjologii węchu, uczenia się $i$ etologii zwierzat, Wydawnictwo Centralnego Laboratorium Kryminalistycznego Komendy Głównej Policji, Warszawa.

Karocki A., Widacki J. (1972), Próby identyfikacji zapachów, "Problemy Kryminalistyki”, 154.

Kołecki H. (1975), Ślad jako zbiór cech identyfikacyjnych, "Problemy Kryminalistyki”, 113.

Kuczys J., Milewski R. (1973), Wykorzystanie psa stużbowego w oględzinach śledczych, “Problemy Kryminalistyki”, 103-104.

Kulicki M. (1994), Kryminalistyka - wybrane zagadnienia teorii i praktyki sq̨dowo-śledczej, Wydawnictwo UMK, Toruń.

Lenkiewicz Z. (1959), Zoopsychologiczne podstawy tresury psa, “Służba MO”, 4-5.

Łachacz M. (1998), Odorologia kryminalistyczna, Dom Organizatora TNOiK, Toruń.

Turin L. (2006), The secret of smell: Adventures in Perfume and the Science of Smell, Harper Collins Publishers, New York.

Widacki J. (1998), Kilka uwag o identyfikacji zapachów ludzkich przez psa na użytek procesu karnego, "Palestra", 11-12.

Wright R.H. (1972), Nauka o zapachu, PWN, Warszawa.

Wójcikiewicz J. (2000), Szkatułka z precjozami a osmologia sqdowa, [in:] Wójcikiewicz J. (ed.), Dowód naukowy $w$ procesie sqdowym, Wydawnictwo Instytutu Ekspertyz Sądowych, Kraków.

Wójcikiewicz J. (2000) (ed.), Dowód naukowy w procesie sq̨owym, Wydawnictwo Instytutu Ekspertyz Sądowych, Kraków. 